\title{
FAKTOR RISIKO KEJADIAN PRE-EKLAMSIA PADA IBU HAMIL DI KABUPATEN BELU
}

\author{
Risk Factors Pre-Eklamsia in Pregnant Mothers, \\ Belu Regency \\ Paulina Ika D.R Bere ${ }^{1}$, Mindo Sinaga ${ }^{2}$, H.A Fernandez ${ }^{2}$ \\ ${ }^{1}$ Bagian KIA-Kespro Program Pascasarjana Universitas Nusa Cendana Kupang. \\ ${ }^{2}$ Dinas Kesehatan Provinsi NTT \\ (ikadewibere82@gmail.com)
}

\begin{abstract}
ABSTRAK
Pre-eklamsia merupakan suatu keadaan patologi yang ditandai dengan adanya hipertensi, proteinuria dan edema. Penelitian ini bertujuan untuk menganalisis faktor risiko dengan kejadian pre-eklamsia pada ibu hamil di Kabupaten Belu. Jenis penelitian yang digunakan adalah penelitian retrospektif dengan desain case control dan menggunakan pendekatan kuantitatif dan kualitatif. Penelitian ini dilaksanakan pada wilayah kerja Puskesmas di Kabupaten Belu, periode Januari-Maret 2015. Analisis statistik yang digunakan adalah chisquare dan Odd Ratio. Besar sampel kasus $40 \mathrm{ibu}$ dan kontrol $40 \mathrm{ibu}$ yang diambil dengan teknik purposive sampling. Hasil penelitian ini ditemukan adanya hubungan yang signifikan antara faktor risiko umur $(p=0,007 ; O R=0,286 ; 95 \% C I=0,133-0,721)$, paritas $(p=0,014 ; O R-0,323 ; 95 \% C I=0,130-0,804)$, riwayat hipertensi $(p=0,007 ; O R=3,462 ; 95 \% \quad C I=1,379-8,691)$, riwayat pre-eklamsia $(p=0,000 ; O R=2,379 ; 95 \% \quad C I=1,803-3,139)$, antenatal care $(\mathrm{p}=0,000 ; \mathrm{OR}=0,140 ; 95 \% \mathrm{CI}=0,052-0,378)$ terhadap kejadian pre-eklamsia. Variabel yang mempunyai risiko terjadinya pre-eklamsia adalah riwayat hipertensi mempunyai risiko 3 kali, riwayat pre-eklamsia mempunyai risiko 2 kali sedangkan variabel umur, paritas dan pemeriksaan kehamilan (ANC) merupakan faktor protektif.
\end{abstract}

Kata kunci: Faktor risiko, pre-eklamsia

ABSTRACT

Pre-eclampsia is a pathological state that is characterized by hypertension, proteinuria and edema.The aim of this study is to analyze pre-eclampsia risk factors in pregnant mothers in Belu Regency. A retrospective study was conducted using a case control design with quantitative and qualitative approaches. The research was conducted in the work area of Belu Regency's community health center from January to March 2015. The statistical analysis used were Chi-Square and Odd Ratio. The sample size of 40 cases in mothers and 40 control mothers were obtained using the purposive sampling technique. The study found a significant correlation between pre-eclampsia cases and age $(p=0,007 ; O R=0,286 ; 95 \% C I=0,133-0,721)$, parity $(p=0,014 ; 0 R-0,323 ; 95 \%$ $C I=0,130-0,804)$, history of hypertension $(p=0,007 ; O R=3,462 ; 95 \% C I=1,379-8,691)$, history of pre-eclampsia $(p=0,000 ; O R=2,379 ; 95 \% C I=1,803-3,139)$, antenatal care $(p=0,000 ; O R=0,140 ; 95 \% C I=0,052-0,378)$. The variables that increased the risk of pre-eclampsia werehistory of hypertension and history of pre-eclampsia, which increased the risk up to three and two times respectively. Meanwhile, age, parity and antenatal care were found to be protective factors.

Keywords : Risk factors, pre-eclampsia 


\section{PENDAHULUAN}

Pre-eklamsia/eklamsia merupakan salah satu penyebab utama kematian ibu di Indonesia. Penyebab kejadian pre-eklamsia pada ibu hamil belum diketahui secara pasti, walaupun telah ada beberapa teori yang mencoba menjelaskan tentang penyebab pre-eklampsia adalah iskemia plasenta. Pre-eklamsia ditandai dengan timbulnya hipertensi, edema dan proteinuria sebagai akibat dari suatu kehamilan yang timbul pada usia kehamilan lebih dari 20 minggu. ${ }^{1}$

Pre-eklamsia/eklamsia merupakan penyebab kedua setelah perdarahan sebagai penyebab langsung yang spesifik terhadap kematian maternal. Di negara berkembang insiden pre-eklamsia dan eklamsia berkisar antara 1:100 sampai 1:1700. Setiap tahun sekitar 50.000 ibu meninggal dunia karena pre-eklamsia. Kejadian pre-eklampsi dapat dikatakan sebagai masalah kesehatan masyarakat apabila Case Fatality Rate (CFR) pre-eklamsia/ eklamsia mencapai 1,4\%-1,8\%. ${ }^{2}$

Hasil Survei Demografi Kesehatan Indonesia (SDKI) tahun 2007 menyebutkan bahwa Angka Kematian Ibu (AKI) sebesar 228 per 100.000 Kelahiran Hidup. Pada tahun 2012 hasil SDKI menunjukkan peningkatan dari 228 per 100.000 Kelahiran Hidup menjadi 359 per $100.000 \mathrm{Ke}-$ lahiran Hidup. ${ }^{3}$ Hasil penilitian Raharja (2012) menunjukkan bahwa di Provinsi Jawa Timur Angka Kematian Ibu (AKI) sebesar 140 per 100.000 Kelahiran Hidup. Dengan penyebab kematian, yaitu perdarahan $(25,09 \%)$, pre-eklamsia/eklamsia $(34,71 \%)$, infeksi $(4,98 \%)$, jantung $(8,25 \%)$ dan lain-lain sebesar (26,98\%). ${ }^{4}$

Angka Kematian Ibu di Provinsi Nusa Tenggara Timur tahun 2013 sebesar 176 per 100.000 Kelahiran Hidup. Dengan penyebab kematian, yaitu perdarahan $(51,13 \%)$, pre-eklamsia/eklamsia $(11,36 \%)$, infeksi $(7,95 \%)$, partus lama $(1,13 \%)$ dan $28,40 \%$ disebabkan oleh faktor lain, sedangkan Angka Kematian Ibu di Kabupaten Belu tahun 2013 sebesar 4 per 100.000 Kelahiran Hidup dengan penyebab utama kematian ibu terbesar adalah infeksi sebesar $50 \% .^{5}$

Kejadian pre-eklamsia sebagai penyebab utama kematian ibu di Kabupaten Belu mengalami peningkatan sejak tahun 2010. Data morbiditas ibu hamil dengan pre-eklamsia periode 2010-2014 sebagai berikut, tahun 2010 sebesar 3,67\%, tahun
2011 sebesar 5,14\%, tahun 2012 sebesar 7,83\%, tahun 2013 sebesar 7,25\% dan tahun 2014 periode Januari-Juni sebesar $8,74 \%$. Sedangkan data mortalitas ibu hamil dan melahirkan karena pre-eklamsia mengalami penurunan yaitu pada tahun 2010 sebesar 1,60\% (1 ibu), tahun 2011 sebesar 0,9\% (2 ibu), tahun 2012 sebesar 0,5\% (1 ibu), tahun 2013 tidak ada kematian ibu karena pre-eklamsia dan tahun 2014 sebesar 0,9\% (1 ibu). ${ }^{6}$

Berdasarkan trend mortalitas kejadian pre-eklamsia di Kabupaten Belu dari tahun 20102014 mengalami penurunan sebesar $0,79 \%$ sedangkan trend morbiditas ibu dengan pre-eklamsia dari tahun 2010-2014, mengalami peningkatan secara signifikan sebesar $7,15 \%$, sehingga dapat diperkirakan kejadian pre-eklamsia per tahun sebesar 1,4\%. ${ }^{7}$ Angka ini menunjukkan adanya masalah kesehatan masyarakat berdasarkan standar CRF yaitu 1,4\%-1,8\%. Tingginya morbiditas kejadian pre-eklamsia pada ibu hamil, tidak menutup kemungkinan dapat meningkat pula mortalitas ibu hamil dan bersalin akibat pre-eklamsia, apabila deteksi dini faktor risiko dan penanganan awal pre-eklamsia tidak dilakukan dengan cepat dan tepat. Tujuan penelitian adalah menganalisis hubungan faktor risiko dengan kejadian pre-eklamsia pada ibu hamil di Kabupaten Belu.

\section{BAHAN DAN METODE}

Penelitian ini menggunakan desain case control (retrospektif). Pelaksanaan penelitian dilakukan pada bulan Januari-Maret 2015. Penelitian ini dilaksanakan pada wilayah kerja Puskesmas di Kabupaten Belu. Variabel independen yang ditentukan adalah umur, paritas, gemelli, riwayat hipertensi, riwayat pre-eklamsia, obesitas, pemeriksaan kehamilan (ANC), health seeking behavior dan sosial budaya gizi. Variabel dependen adalah pre-eklamsia. Populasi kasus dalam penelitian ini adalah seluruh ibu hamil yang mengalami pre-eklamsia di Kabupaten Belu berjumlah 45 ibu periode Juni-Desember 2014. Penentuan sampel mengacu pada teori R.V Kreejie dan D.W Morgan, dengan total populasi 45 ibu sehingga sampel yang ditentukan berjumlah $40 \mathrm{ibu}$ sampel kasus dan 40 ibu sampel kontrol diperoleh dengan teknik random pada seluruh ibu hamil normal, dengan perbandingan 1:1. Pengambilan sampel menggunakan teknik purposive sampling. Data kuantitatif 
diperoleh dengan cara pengumpulan data primer menggunakan kuesioner sedangkan data kualitatif diperoleh dengan cara Focus Group Discussion (FGD). Teknik analisis yang digunakan adalah analisis univariat, bivariat menggunakan chi square dilanjutkan dengan menghitung besaran risiko menggunakan Odd Ratio. Data disajikan dalam bentuk tabel disertai narasi.

\section{HASIL}

Tabel 1 menunjukkan proporsi umur ibu hamil yang mengalami pre-eklamsia dengan presentase tertinggi terjadi pada kelompok umur 2035 tahun sebesar $28(63,6 \%)$ dan presentase paling rendah terjadi pada kelompok umur $<20->35$ tahun sebesar $12(33,3 \%)$. Demikian pula pada ibu hamil yang tidak mengalami pre-eklamsia, presentase paling banyak terjadi pada kelompok umur $<20->35$ tahun sebesar $24(66,7 \%)$ dan presentase paling rendah terjadi pada kelompok umur 20-35 tahun sebesar $16(36,4 \%)$. Sehingga ada perbedaan proporsi umur antara kelompok kasus dan kelompok kasus yaitu kejadian pre-eklamsia tertinggi terjadi pada umur 20-35 tahun sedangkan kelompok kontrol kejadian pre-eklamsia tertinggi pada kelompok umur $<20->35$ tahun.

Proporsi paritas yang mengalami pre-eklamsia dengan presentase tertinggi terjadi pada kelompok multigravida sebesar $25(64,1 \%)$ dan presentase paling rendah terjadi pada kelompok primigravida dan grandemultigravida sebesar 15 $(36,6 \%)$. Demikian pula pada ibu hamil yang tidak mengalami pre-eklamsia, proporsi yang paling banyak terjadi pada kelompok paritas primigra-

Tabel 1. Distribusi Responden Berdasarkan Faktor Risiko Kejadian Pre-Eklamsia

\begin{tabular}{|c|c|c|c|}
\hline \multirow[b]{2}{*}{ Variabel } & \multicolumn{2}{|c|}{ Pre Eklamsia } & \multirow{2}{*}{$\begin{array}{l}\text { Total } \\
\text { n(\%) }\end{array}$} \\
\hline & $\begin{array}{c}\text { Ya } \\
\mathbf{n}(\%)\end{array}$ & $\begin{array}{l}\text { Tidak } \\
\text { n(\%) }\end{array}$ & \\
\hline \multicolumn{4}{|l|}{ Umur } \\
\hline$\geq 35$ tahun & $12(33,3)$ & $24(66,7)$ & $36(100)$ \\
\hline$<35$ tahun & $28(63,6)$ & $16(36,4)$ & $44(100)$ \\
\hline \multicolumn{4}{|l|}{ Paritas } \\
\hline Primi \& Grande & $15(36,6)$ & $26(63,4)$ & $41(100)$ \\
\hline Multigravida & $25(64,1)$ & $14(35,9)$ & $39(100)$ \\
\hline \multicolumn{4}{|l|}{ Gemelli } \\
\hline Gemelli & $1(50)$ & $1(50)$ & $2(100)$ \\
\hline Tunggal & $39(50)$ & $39(50)$ & $78(100)$ \\
\hline \multicolumn{4}{|l|}{ Riwayat Hipertensi } \\
\hline Ada & $25(65,8)$ & $13(34,2)$ & $38(100)$ \\
\hline Tidak ada & $15(35,7)$ & $27(64,3)$ & $42(100)$ \\
\hline \multicolumn{4}{|l|}{ Riwayat Pre-eklamsia } \\
\hline Ada & $11(100)$ & $0(0)$ & $11(100)$ \\
\hline Tidak ada & $29(42)$ & $40(58)$ & $69(100)$ \\
\hline \multicolumn{4}{|l|}{ Obesitas } \\
\hline Obesitas & $16(51,6)$ & $15(48,4)$ & $31(100)$ \\
\hline Normal & $24(49)$ & $25(51)$ & $49(100)$ \\
\hline \multicolumn{4}{|c|}{ Pemeriksaan kehamilan (ANC) } \\
\hline$<4$ Kali & $13(29,5)$ & $31(70,5)$ & $44(100)$ \\
\hline$>4$ Kali & $27(75)$ & $9(25)$ & $36(100)$ \\
\hline \multicolumn{4}{|c|}{ Health Seeking Behavior } \\
\hline Kurang & $22(45,8)$ & $26(54,2)$ & $48(100)$ \\
\hline Baik & $18(56,2)$ & $14(43,8)$ & $32(100)$ \\
\hline \multicolumn{4}{|l|}{ Sosial Budaya Gizi } \\
\hline Kurang & $29(53,7)$ & $25(46,3)$ & $54(100)$ \\
\hline Baik & $11(42,3)$ & $15(57,7)$ & $26(100)$ \\
\hline
\end{tabular}

Sumber : Data Primer, 2015 
Tabel 2. Hasil Analisis Bivariat Faktor Risiko Kejadian Pre-eklamsia

\begin{tabular}{lcccc}
\hline \multicolumn{1}{c}{ Variabel } & \multirow{2}{*}{$\mathbf{~}$} & & \multicolumn{2}{c}{$\mathbf{9 5 \%}$ Confidence Interval } \\
\cline { 4 - 5 } & & & Lower & Upper \\
\hline Umur & 0,007 & 0,286 & 0,113 & 0,721 \\
Paritas & 0,014 & 0,323 & 0,130 & 0,804 \\
Gemelli & 1,000 & 1,000 & 0,060 & 16,562 \\
Riwayat Hipertensi & 0,007 & 3.462 & 1,379 & 8,691 \\
Riwayat Pre-eklamsia & 0,000 & 2,379 & 1,803 & 3,139 \\
Obesitas & 0,818 & 1,111 & 0,452 & 2,733 \\
Pemeriksaan Kehamilan (ANC) & 0,000 & 0,140 & 0,052 & 0,378 \\
Health Seeking Behavior & 0,361 & 0,658 & 0,268 & 1,619 \\
Sosial Budaya Gizi & 0,340 & 1,582 & 0,615 & 4,066 \\
\hline
\end{tabular}

Keterangan: Signifikan $\mathrm{p}<0,05$

vida dan grandemultigravida sebesar $26(63,4 \%)$ dan proporsi terendah terjadi pada paritas multigravida sebesar 14 (35,9\%). Sehingga terdapat perbedaan proporsi paritas yang paling banyak terjadi pre-eklamsia pada kelompok kasus adalah multigravida, sedangkan kelompok kontrol paling banyak tidak mengalami pre-eklamsia terjadi pada primigravida dan grandemultigravida.

Proporsi ibu hamil dengan riwayat hipertensi yang mengalami pre-eklamsia, presentase tertinggi terjadi pada kelompok ada riwayat hipertensi sebesar $25(65,8 \%)$ dan presentase paling rendah terjadi pada kelompok tidak ada riwayat hipertensi sebesar 15 (35,7\%). Demikian pula pada ibu hamil yang tidak mengalami pre-eklamsia, presentase tertinggi terjadi pada kelompok tidak ada riwayat hipertensi sebesar $27(64,3 \%)$ dan presentase paling rendah terjadi pada kelompok ada riwayat hipertensi sebesar 13 (34,2\%). Sehingga terdapat perbedaan proporsi variabel riwayat hipertensi yang paling banyak mengalami pre-eklamsia terjadi pada kelompok kasus adalah ada riwayat hipertensi, sedangkan kelompok kontrol paling banyak tidak mengalami pre-eklamsia terjadi pada kelompok tidak ada riwayat hipertensi.

Proporsi ibu hamil dengan riwayat pre-eklamsia yang mengalami pre-eklamsia, presentase tertinggi terjadi pada kelompok tidak ada riwayat pre-eklamsia sebesar $29(42 \%)$ dan presentase paling rendah terjadi pada kelompok ada riwayat pre-eklamsia sebesar $11(100 \%)$. Demikian pula pada ibu hamil yang tidak mengalami pre-eklamsia, presentase tertinggi terjadi pada kelompok tidak ada riwayat hipertensi sebesar $40(58 \%)$ dan kelompok ada riwayat pre-eklam- sia adalah nol. Jadi tidak ada perbedaan proporsi riwayat pre-eklamsia antara kelompok kasus dan kelompok kontrol yaitu sama - sama pada kelompok tidak ada riwayat pre-eklamsia.

Proporsi ibu hamil dengan frekuensi pemeriksaan kehamilan (ANC) yang mengalami pre-eklamsia dengan presentase tertinggi terjadi pada kelompok ANC >4 kali sebesar 27 (75\%) dan presentase paling rendah terjadi pada kelompok ANC <4 kali sebesar 13 (29,5\%). Demikian pula ibu hamil yang tidak mengalami pre-eklamsia, presentase paling banyak terjadi pada kelompok ANC $<4$ kali sebesar $31(70,5 \%)$ dan presentase paling rendah terjadi pada kelompok ANC $>4$ kali sebesar 9 (25\%). Sehingga terdapat perbedaan proporsi variabel pemeriksaan kehamilan (ANC) yang paling banyak terjadi pre-eklamsia pada kelompok kasus adalah ANC $>4$ kali, sedangkan kelompok kontrol paling banyak tidak mengalami pre-eklamsia terjadi pada kelompok ANC $<4$ kali.

Tabel 2 menunjukkan hasil analisis bivariat diketahui dari 9 (sembilan) variabel yang dianalisis ditemukan 5 (lima) variabel yang mempunyai hubungan bermakna yaitu variabel umur, variabel paritas, variabel riwayat hipertensi, variabel riwayat pre-eklamsia dan variabel pemeriksaan kehamilan (ANC). Risiko terjadinya pre-eklamsia 3,4 kali lebih besar pada ibu hamil dengan adanya riwayat hipertensi dan 2,3 kali lebih besar pada ibu hamil yang memiliki riwayat pre-eklamsia pada kehamilan sebelumnya. Sedangkan variabel umur, paritas dan pemeriksaan kehamilan (ANC) merupakan faktor protektif dalam penelitian ini, sehingga apabila upaya pencegahan dapat dilakukan dengan baik maka kejadian pre-eklamsia pada 
ibu hamil dapat dikendalikan.

\section{PEMBAHASAN}

Dalam penelitian ini diketahui ada 5 (lima) variabel yang mempunyai hubungan bermakna dengan kejadian pre-eklamsia yaitu variabel umur, paritas, riwayat hipertensi, riwayat pre-eklamsia dan pemeriksaan kehamilan. Untuk besar risikoditemukan 2,3 kali lebih besar pada ibu hamil dengan riwayat hipertensi pada kehamilan sebelumnya.

Usia reproduksi sehat pada seorang wanita adalah 20-35 tahun. Kelompok umur ini mampu mengurangi risiko kematian ibu karena pre-eklamsia maupun karena penyebab lain dari kematian ibu di Indonesia. Umur $<20$ tahun dan $>35$ tahun termasuk usia yang berisiko untuk bereproduksi. Kelompok usia ini dapat termasuk salah satu penyebab langsung kematian ibu yang sering disebut dengan Terlalu Muda dan Terlalu Tua. ${ }^{8}$ Hasil analisis ditemukan ada hubungan yang signifikan antara faktor risiko umur dengan kejadian pre-eklamsia dengan nilai $\mathrm{OR}=0,286(0,113$ 0,721 ) dan nilai $p=0,007$. Dalam penelitian ini pre-eklamsia ditemukan lebih banyak pada umur reproduksi normal yaitu 20-35 tahun. Hasil ini sejalan dengan temuan Wuryandari, bahwa frekuensi kejadian pre-eklamsia terbanyak pada kelompok umur 20-35 tahun. ${ }^{9}$ Namun, tidak sejalan dengan pendapat Robson, dkk., bahwa ibu hamil dengan umur $<20$ dan $>35$ tahun merupakan faktor risiko terjadinya pre-eklampsia selain penyakit vaskuler dan ginjal, diabetes mellitus, hipertensi kronis dan penyakit lainnya. ${ }^{10}$ Didukung temuan Abalos, et, al., bahwa ada hubungan yang signifikan antara usia ibu $>35$ tahun dengan kejadian pre-eklamsia. Peneliti yang sama juga mengatakan bahwa remaja (usia $<19$ tahun) tidak terdapat hubungan dengan kejadian pre-eklamsia, tetapi memiliki risiko terjadi eklamsia. ${ }^{11}$ Dari pernyataan tersebut dapat disimpulkan bahwa pengelompokkan usia merupakan salah satu faktor penting dalam program Kesehatan Ibu dan Anak di Indonesia. Tidak menutup kemungkinan bahwa pre-eklamsia bisa terjadi pada kelompok umur wanita produktif yang aman untuk kehamilan dan persalinan yaitu antara umur 20-35 tahun. Sehingga setiap wanita yang hamil pada kelompok umur $<20$ dan $>35$ tahun maupun pada umur reproduksi normal antara umur 20-35 tahun wajib dilakukan pemantauan kehamilan yang intensif agar dapat meminimalkan faktor risiko yang mungkin terjadi melalui kunjungan Ante Natal Care (ANC) yang memadai dan teratur.

Paritas adalah banyaknya kelahiran hidup atau jumlah anak yang dimiliki oleh seorang wanita. Faktor paritas memiliki pengaruh terhadap persalinan dikarenakan ibu hamil memiliki risiko lebih tinggi untuk mengalami gangguan selama masa kehamilannya terlebih pada ibu yang pertama kali mengalami masa kehamilan. Pre-eklamsia tidak hanya dialami oleh primigravida/primipara, tetapi dapat terjadi juga pada ibu multipara dan grandemultipara. ${ }^{12}$ Hasil analisis ditemukan adanya hubungan yang signifikan antara faktor risiko paritas dengan kejadian pre-eklamsia dengan nilai $\mathrm{OR}=0,323(0,130-0,804)$ dan nilai $p=0,014$. Temuan ini sejalan dengan penelitian dari Rozikhan, bahwa ada hubungan yang signifikan antara partus anak pertama dengan kejadian pre-eklamsia dengan nilai $\mathrm{p}=0,001, \mathrm{OR}=4,751$ dan $95 \% \mathrm{CI}=2,227-10,134 .{ }^{3}$ Penelitian yang sama oleh Suwanti, dkk., bahwa ada hubungan signifikan antara paritas dengan kejadian pre-eklamsia dengan nilai $\mathrm{p}=0,035$ dan $\mathrm{OR}=4,800 .{ }^{11}$ Teori imunologis mengemukakan bahwa pada primigravida/primipara terjadi pembentukan blocking antibodies terhadap antigen tidak sempurna sehingga dapat menghambat invasi arteri spiralis ibu oleh trofoblas sampai batas tertentu sehingga dapat mengganggu fungsi plasenta. ${ }^{13}$ Pencegahan pre-eklamsia sangat terbatas karena etiologinya belum diketahui. Pemeriksaan dengan penapisan belum dapat menunjukkan hasil yang memadai untuk mengetahui faktor risiko pre-eklamsia. Oleh karena itu, bidan perlu melakukan pendekatan yang bijaksana dengan mengidentifikasi ibu hamil yang berisiko atau ibu hamil yang menunjukan gejala. Faktor risiko tersebut biasanya dapat diketahui melalui pengkajian riwayat penyakit pada ibu hamil dan hasil pemeriksaan yang dilakukan dengan teliti. Berbagai faktor risiko tersebut memiliki perannya masing-masing dan interaksi faktor risiko ini tidak sepenuhnya dapat dipahami. Namun, terdapat kecenderungan bahwa seorang ibu hamil yang lebih banyak memiliki faktor risiko umumnya akan menunjukkan keadaan yang lebih buruk. 
Hipertensi dalam kehamilan didefinisikan sebagai tekanan darah sistolik $\geq 140 \mathrm{mmHg}$ dan atau tekanan darah diastolik $\geq 90 \mathrm{mmHg}$. Signifikasi setiap pengukuran tekanan darah berhubungan dengan usia gestasi dalam kehamilan dan umumnya semakin awal hipertensi terjadi dalam kehamilan, semakin besar kemungkinan hipertensi tersebut menjadi kronis. ${ }^{14}$ Hasil analisis ditemukan ada hubungan yang signifikan antara faktor risiko riwayat hipertensi dengan kejadian pre-eklamsia dengan nilai $\mathrm{OR}=3,462(1,379$ $8,691)$ dan nilai $p=0,007$. Hasil ini sejalan dengan penelitian Safitri, dkk., bahwa ada hubungan yang signifikan antara riwayat penyakit dengan kejadian pre-eklamsia dengan nilai $\mathrm{p}=0,000$ dan $\mathrm{OR}=3,877 .{ }^{15}$ Didukung dengan hasil penelitian $\mathrm{Bi}$ lano, et, al., bahwa faktor risko riwayat hipertensi memiliki hubungan secara signifikan dan meningkat 3 kali lebih besar terjadi pre-eklamsia. ${ }^{13} \mathrm{Pe}$ ran bidan dalam hubungannya dengan gangguan tekanan darah pada kehamilan terletak pada ketelitiannya melakukan pemeriksaan, mengidentifikasi dini dan melakukan konsultasi, kolaborasi dengan dokter. Pre-eklamsia dapat menimbulkan dampak yang sangat serius pada ibu dan janin. Oleh karena itu, mempertahankan tingkat kecurigaan yang tinggi dan menghindari asumsi berlebihan bahwa temuan yang diperoleh menunjukkan kondisi normal akan membantu menegakkan diagnosis yang benar dan penanganan yang tepat.

Faktor risiko riwayat pre-eklamsia biasanya dapat diketahui melalui pengkajian awal riwayat penyakit ibu hamil dan hasil pemeriksaan yang dilakukan dengan teliti. Berbagai faktor risiko tersebut memiliki perannya masing-masing, tetapi terdapat kecenderungan bahwa seorang ibu hamil yang lebih banyak memiliki faktor risiko umum-nya akan menunjukkan keadaan yang lebih buruk. ${ }^{16}$ Hasil penelitian ditemukan ada hubungan yang signifikan antara faktor risiko riwayat pre-eklamsia dengan kejadian pre-eklamsia dengan nilai $\mathrm{OR}=2,379(1,803-3,139)$ dan nilai $\mathrm{p}=0,000$. Penelitian Robson, dkk, menyatakan bahwa terdapat banyak faktor risiko yang menjadi faktor predisposisi terjadinya pre-eklamsia, salah satunya adalah riwayat pre-eklamsia dan ditemukan kejadian pre-eklamsia akan meningkat 7 kali lipat pada ibu hamil yang pernah mengalami pre-eklamsia pada hamil sebelumnya. ${ }^{10}$ Per- nyataan yang sama juga kemukakan oleh Vivian, dkk., bahwa ibu hamil dengan riwayat pre-eklamsia akan meningkat $25 \%$ terjadinya pre-eklamsia pada kehamilan sekarang. ${ }^{8}$

Pemeriksaan kehamilan atau asuhan Ante natal Care (ANC) merupakan suatu proses pemeriksaan yang dilakukan sejak mulai masa kehamilan sampai saat proses persalinan dan pemeriksaan masa kehamilan ini dilakukan untuk mengawasi dan memonitor kesehatan ibu dan bayi sehingga proses kehamilan hingga persalinanya dapat berjalan sesuai yang diharapkan. ${ }^{17}$ Hasil penelitian ditemukan ada hubungan yang signifikan antara faktor risiko pemeriksaan kehamilan (ANC) dengan kejadian pre-eklamsia dengan nilai $\mathrm{OR}=0,140(0,052-0,378)$ dan nilai $\mathrm{p}=0,000$. Penelitian ini sejalan dengan Langelo, et, al., bahwa terdapat hubungan yang bermakna antara pemeriksaan kehamilan dengan kejadian pre-eklamsia dengan nilai $\mathrm{p}=0,000$ dan nilai Odd Ratio $=2,72$ dengan tingkat kepercayaan $95 \% \mathrm{CI}=1,39-5,33 .{ }^{13}$ Hasil penelitian ini juga ditemukan $70,5 \%$ ibu hamil yang melakukan pemeriksaan kehamilan $<4$ kali. Hal ini disebabkan oleh banyak faktor antara lain; masyarakat belum mengetahui tentang manfaat pemeriksaan kehamilan, faktor demografi sebagai alasan masyarakat khususnya ibu hamil tidak melakukan pemeriksaan kehamilan, jarak tempuh ke sarana pelayanan kesehatan yang sangat jauh, petugas kesehatan yang sering tidak berada di tempat pelayanan, sehingga masih ada persalinan yang ditolong oleh dukun. Demikian juga masih ditemukan ibu hamil yang tinggal di daerah perkotaan belum melakukan pemeriksaan kehamilan secara teratur.

Berdasarkan hasil temuan ini, diharapkan agar tenaga kesehatan khususnya bidan senantiasa dapat meningkatkan ilmu pengetahuan dan keterampilannya untuk mendeteksi faktor risiko pada ibu hamil, khususnya ibu hamil dengan pre-eklamsia, sehingga dapat memberikan informasi dan tindakan yang tepat dalam memberikan asuhan kebidanan pada ibu hamil yang berisiko. Fasilitas kesehatan berhubungan erat dengan tempat ibu untuk mendapatkan pelayanan kesehatan yaitu memeriksakan kehamilannya hingga ibu dapat melahirkan dengan aman dan selamat. Oleh karena tingkat pendidikan dan pemahaman masyarakat yang bervariasi, maka bidan dituntut 
untuk mampu memberikan informasi yang tepat tentang faktor risiko pada ibu hamil dan cara deteksi faktor risiko yang benar pada ibu hamil dan keluarga serta pemanfaatan fasilitas pelayanan kesehatan secara maksimal yang ada disekitarnya seperti rumah bersalin, polindes, puskesmas maupun fasilitas kesehatan lainnya yang aman bagi kehamilan dan persalinannya.

\section{KESIMPULAN DAN SARAN}

Ditemukan adanya hubungan yang signifikan antara faktor risiko umur, paritas, riwayat hipertensi, riwayat pre-eklamsia dan pemeriksaan kehamilan (ANC) dengan kejadian pre-eklamsia. Diharapkan ada peningkatan pengetahuan, wawasan dan mutu pelayanan khususnya dalam melakukan deteksi dini faktor risiko pada ibu hamil dan penanganan kehamilan dengan risiko tinggi maupun komplikasi, terutama penanganan yang cepat dan tepat pada ibu hamil dengan pre-eklamsia yang disebabkan oleh faktor risiko yang telah dikemukakan dalam penelitian ini.

\section{DAFTAR PUSTAKA}

1. Wiknjosastro, H. Ilmu Kebidanan. Jakarta : Penerbit YBP-SP; 2006.

2. Wahyuny, dkk. Faktor Risiko Kejadian Pre-eklamsia di RSKD Ibu dan Anak Siti Fatimah Makassar Tahun 2011-2012.

3. Rozikhan. Faktor-Faktor Risiko Terjadinya Pre-eklamsia Berat di Rumah Sakit Dr. H. Soewando Kendal [Tesis]. Semarang: Universitas Diponegoro: 2007

4. Raharja, Risiko Kematian Ibu Menurut Usia Pada Kasus Kematian Ibu Dengan Pre Eklamsia di Provinsi Jawa Timur. Jurnal. 2013.

5. Profil Dinas Kesehatan Provinsi Nusa Tenggara Timur Tahun 2014.

6. Laporan Tahunan Rumah Sakit Umum Mrg. Gabriel Manek, SVD Atambua. Tahun 2014.

7. Profil Dinas Kesehatan Kabupaten Belu Tahun 2014.

8. Vivian Nanny, dkk.. Asuhan Kehamilan untuk Kebidanan. Jakarta : Salemba Medika; 2011.

9. Wuryandari, Faktor-Faktor yang Berhubungan dengan Kejadian Pre-eklamsia di RSUD
Raden Mattaher Jambi. Online-Journal. 2012.

10. Robson dan Waugh. Patologi pada Kehamilan. Jakarta : Buku Kedokteran EGC. Jakarta; 2013.

11. Suwanti, dkk. Hubungan Tekanan Darah dan Paritas Dengan Kejadian Pre-eklamsia Di Ruang Bersalin RSUP NTB. Jurnal. Media Bina Ilmiah. 2012; ISSN No. 1978-3787.

12. E. Abalos, et, al., Pre-eclamsia, Eclampsia and Adverser Maternal and Perinatal Outcome: a Secondary Analysis of the world Health Organization Multicountry Survey on Maternal and Newborn Health. Original Article. 2013.

13. Ver Luanni Bilano, Erika Ota, Togoobaatar Ganchimeg, Rintaro Mori dan Joao Paulo Souza, "Risk Factors of Pre-Eclampsia/ Eclampsia and Its Adverse Outcomes in Lowand Middle-Income Countries: A WHO Secondary Analysis" Journal PLOS ONE, 2014; 9(3).

14. Christina W. Chen, et, al. Pre-eclampsia and cardiovascular disease. Received 18 November 2013; revised 20 January 2014; accepted 21 January 2014; online publish-ahead-ofprint 13 February 2014.

15. Safitri, dkk. Hubungan Tekanan Darah dan Paritas dengan Kejadian Eklamsia di Ruang Besalin RSUP NTB. Media Bina Ilmiah. 2014;8(1). ISSN No. 1978-3787.

16. D Berks, et al. Risk of Cardiovascular Disease after Pre-eclampsia and the Effect of Lifestyle Interventions: a Literature-Based Study. Journal Maternal medicine; 2013.

17. Rukiyah, dkk. Asuhan Kebidanan I (Kehamilan). Cetakan Pertama. Penerbit CV. Trans Info Media; 2009.

18. Martini, dkk. Hubungan Antara Gaya Hidup Selama Masa Kehamilan dengan Kejadian Pre-eklamsia. The Indonesian Journal of Public Health. Maret 2012;8(2):122-125.

19. Imelda, dkk. Faktor - faktor yang Berhubungan dengan Kejadian Pre-eklamsia pada Ibu Hamil di Poli Kebidanan Rumah Sakit Kesdam Banda Aceh. 2013.

20. Yulianti. Manajemen Komplikasi Kehamilan dan Persalinan. Cetakan I. Jakarta : Kedokteran EGC; 2006. 